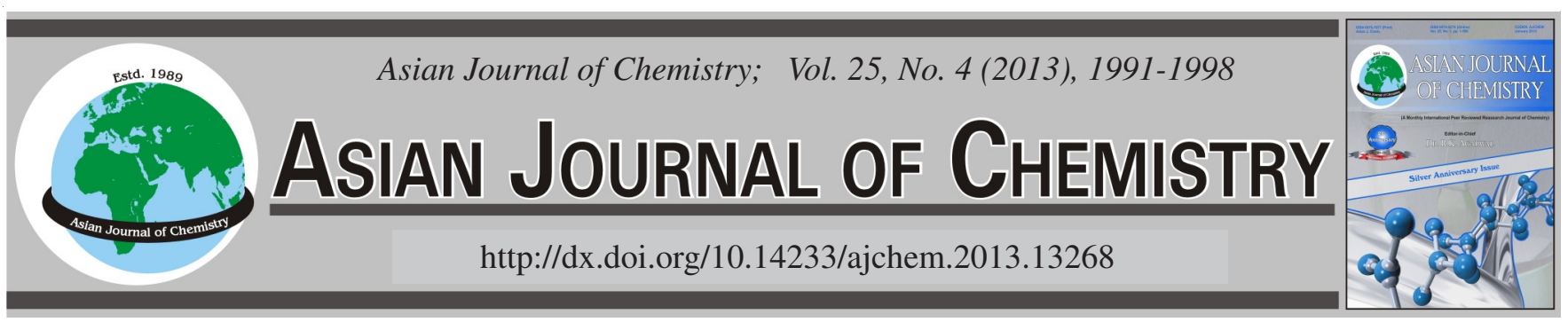

\title{
Removal of Auramine O from Aqueous Solution Using Sesame Leaf: Adsorption Isotherm and Kinetic Studies
}

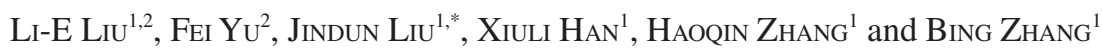

${ }^{1}$ School of Chemical Engineering and Energy, Zhengzhou University, Zhengzhou 450001, P.R. China

${ }^{2}$ School of Public Health, Zhengzhou University, Zhengzhou 450001, P.R. China

*Corresponding author: Tel: +86 136 08699960, E-mail: zzdxlle66@zzu.edu.cn, liujindun@zzu.edu.cn

\begin{abstract}
The potential of sesame leaf was used to remove Auramine $\mathrm{O}$ from aqueous solution. The experiments were carried out under various conditions of solution $\mathrm{pH}$, initial concentration, contact time, adsorbent dose, salt ionic strength and temperature. Adsorption isotherms were evaluated by the Langmuir, Freundlich and Redlich-Peterson isotherm models. The results of analysis indicated that the equilibrium data were fitted well with the Redlich-Peterson isotherm model. The maximum adsorption capacity of sesame leaf was found to be 249.2 $\mathrm{mg} \mathrm{g}^{-1}$ at $293 \mathrm{~K}$. The kinetic studies indicated that the pseudo-second-order equation is the best model that describes the adsorption behaviour. The thermodynamic parameters like $\Delta \mathrm{G}^{\circ}, \Delta \mathrm{H}^{\circ}$ and $\Delta \mathrm{S}^{\circ}$ were calculated and the results indicated that the adsorption of Auramine $\mathrm{O}$ onto sesame leaf was a spontaneous and exothermic process in nature. This study implied that sesame leaf was a potential candidate as an economic biosorbent for the removal of Auramine $\mathrm{O}$ from aqueous solution.
\end{abstract}

Key Words: Adsorption, Auramine O, Sesame leaf, Isotherm, Kinetics.

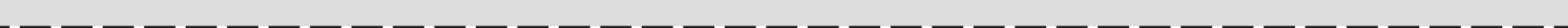

\section{INTRODUCTION}

In order to make the world more beautiful, various dyes are widely applied in many industries to decorate their products. These industries include not only textile and printing but also cosmetics, leather, paper, food, plastics, construction, etc. However, the dyes that are beautifying our lives are also creating great environmental pollution. In order to keep the colour for a long time, the dyes usually have complex molecular structures ${ }^{1}$, which make them more stable and difficult to biodegrade. In addition, the dye bath effluents contain large amounts of surfactants, salts and heavy metals, have deeper colour, extreme $\mathrm{pH}$ and higher COD values. The wastewater released into lands and rivers in the global is not a visual pollution, it is also a great threat for the health of many forms of life. Thus, to eliminate the stable dyes from wastewater is a major concern. There are several biological, chemical or physical methods typically used in treating dye wastewater such as photo or photocatalytic degradation $^{2-4}$, biodegradation ${ }^{5,6}$, electrochemical degradation ${ }^{7,8}$, membrane technology $y^{9,10}$, activated carbon adsorption ${ }^{11,12}$ and integrated method degradations ${ }^{13,14}$. Adsorption is a popular method due to its effectiveness and convenience ${ }^{15,16}$. In recent years, many natural materials and byproducts from agriculture and industry have been utilized as low cost adsorbents to substitute expensive activated carbon, which enlarges the application scope of adsorption. These materials include corn husks ${ }^{17-19}$, fruit peel and seeds ${ }^{20,21}$, bottom ash and de-oiled soya ${ }^{22,23}$, fallen leaves ${ }^{24,25}$, etc. ${ }^{26-28}$.

Sesame is extensively cultured in China. Sesame leaf is an abundant agricultural by-product and usually discarded after harvest, which is not only wasteful but also pollutes the environment. The sesame leaf contains plenty of floristic fiber, flavonoids, fatty acid, protein, polysccharides and some functional groups, which make biosorption process possible ${ }^{29}$.

Auramine $\mathrm{O}$ is a cationic dye commonly used in industries for dying the products ${ }^{30}$. In this paper, the sesame leaf was used as adsorbent to remove Auramine $\mathrm{O}$ from aqueous solutions. Some key parameters such as isotherm constants and adsorption kinetics were obtained and the effect factors such $\mathrm{pH}$, temperature, sesame leaf dose, contact time $(\mathrm{t})$ and initial Auramine $\mathrm{O}$ concentration $\left(\mathrm{C}_{0}\right)$ were investigated. The results indicate that sesame leaf can be used as an economic and efficient adsorbent for removal of Auramine $\mathrm{O}$ from wastewater and is valuable for further application of sesame leaf in dye removal.

\section{EXPERIMENTAL}

Preparation and characterization of sesame leaf: Sesame leaf used in present research was collected from its natural habitats located at Zhumadian, Henan Province, China. 
The material was first soaked and extensively brushed with tap water to get rid of all the dirt and then washed several times with distilled water. The spotless sample was dried at $60{ }^{\circ} \mathrm{C}$ for $15 \mathrm{~h}$ in an oven, then ground into powder and sifted through a nest of sieves to get 20-40 mesh size. The prepared sample was enclosed in a self-sealing plastic pocket and preserved in the desiccator for using in subsequent investigations. Surface texture of sesame leaf was analyzed by scanning electron microscopy (JEOL 6335F-SEM, Japan). Fourier transform infrared spectrometer (Hitachi S-4700, Japan) was used to analyze the functional groups on the surface of sesame leaf. The spectral range varied from 4000 to $400 \mathrm{~cm}^{-1}$.

Preparation of Auramine $\mathbf{O}$ solutions: The adsorbate Auramine O dye (C.I. no: 41000, FW= 303.84) was supplied by Guoyao Chemical Equipment Company. The stock solution with the concentration of $1.0 \mathrm{~g} \mathrm{~L}^{-1}$ was prepared by accurately weighing and dissolving $1.0 \mathrm{~g}$ of Auramine $\mathrm{O}$ in $1 \mathrm{~L}$ of distilled water and was diluted into the needed concentration with distilled water when it was used in the next investigation.

Experimental methods of adsorption: In each batch biosorption experiment, $0.02 \mathrm{~g}$ sesame leaf was agitated with $20 \mathrm{~mL}$ Auramine $\mathrm{O}$ solution of several accurate concentrations in a $100 \mathrm{~mL}$ conical flask for predetermined time intervals at $120 \mathrm{rpm}$ at different temperatures 293, 303 and $313 \mathrm{~K}$. The effect of solution $\mathrm{pH}$ on the amount of Auramine $\mathrm{O}$ adsorbed onto adsorbent was investigated over the $\mathrm{pH}$ range from 1.911.0. The initial solution $\mathrm{pH}$ was adjusted using $0.1 \mathrm{~mol} \mathrm{~L}^{-1}$ $\mathrm{NaOH}$ or $0.1 \mathrm{~mol} \mathrm{~L}^{-1} \mathrm{HCl}$. The effect of salt ionic strength on the removal of Auramine $\mathrm{O}$ was discussed over the $\mathrm{NaCl}$ or $\mathrm{CaCl}_{2}$ concentration range from 0.05 to $0.30 \mathrm{~mol} \mathrm{~L}^{-1}$. For kinetic and isothermal studies, a series of $100 \mathrm{~mL}$ flask were used and each flask was filled with sesame leaf powder at mass loadings $1.0 \mathrm{~g} \mathrm{~L}^{-1}$ for Auramine $\mathrm{O}$ solution at different initial concentrations $(20 \mathrm{~mL})$, respectively. After adsorption, the mixture of dye and sorbent was separated by centrifugation at $4000 \mathrm{rpm}$ for $20 \mathrm{~min}$ and the concentration of remaining dye in supernatant was analyzed by a double-beam UV-VIS spectrophotometer (Shimadzu Brand UV-1601) at the maximum absorbance wavelength $(432 \mathrm{~nm})$. The amount of dye adsorbed onto per gram of adsorbent (q) and the percentage removal efficiency (R) were calculated using eqns. (1) and (2), respectively $^{27}$ :

$$
\begin{gathered}
\mathrm{q}=\frac{\mathrm{V}\left(\mathrm{C}_{0}-\mathrm{C}\right)}{\mathrm{m}} \\
\mathrm{R}=\frac{\left(\mathrm{C}_{0}-\mathrm{C}\right)}{\mathrm{C}_{0}} \times 100 \%
\end{gathered}
$$

where, $\mathrm{q}$ is the adsorbed amount of Auramine $\mathrm{O}$ by sesame leaf in $\mathrm{mg} \mathrm{g}^{-1}, \mathrm{C}_{0}$ and $\mathrm{C}$ are the initial and remaining Auramine $\mathrm{O}$ concentration in $\mathrm{mg} \mathrm{L}^{-1}$, respectively, $\mathrm{V}$ is the volume of the solution in $\mathrm{L}$ and $\mathrm{m}$ is the mass of sesame leaf in $\mathrm{g}$.

Modeling of kinetic and isothermal data was carried out by a non-linear or linear regression methods. Two error functions, i.e., coefficient of determination $\left(\mathrm{R}^{2}\right)$ and chi-square statistic $\left(\chi^{2}\right)$ were used to measure the degree of fitness of theoretical models with the experimental sorption data. The values of $\mathrm{R}^{2}$ were obtained directly from a Origin 8.0 function, while $\chi^{2}$ was calculated using the equation (3):

$$
\chi^{2}=\sum \frac{\left(\mathrm{q}_{\mathrm{ex}}-\mathrm{q}_{\mathrm{pr}}\right)^{2}}{\mathrm{q}_{\mathrm{pr}}}
$$

where, $\mathrm{q}_{\mathrm{ex}}$ and $\mathrm{q}_{\mathrm{pr}}\left(\mathrm{mg} \mathrm{g}^{-1}\right)$ are experimental and predicted amounts of dye adsorbed, respectively, at time ' $t$ ' or at equilibrium.

If data from model are similar to the experimental data, $\chi^{2}$ will be a small number.

\section{RESULTS AND DISCUSSION}

Characteristics of sesame leaf: The FTIR technique is an important tool to identify some characteristic functional groups, which make adsorbing dye ions possible. The FTIR of sesame leaf shows the broad and intense absorption peaks at around $3403.96 \mathrm{~cm}^{-1}$ exhibit the $\mathrm{O}-\mathrm{H}$ stretching vibrations due to inter- and intra-molecular hydrogen bonding of polymeric compounds, such as alcohols, phenols and carboxylic acids, as in pectin, cellulose and lignin, thus, showing the presence of free hydroxyl groups on the adsorbent surface. The peak at $2925.08 \mathrm{~cm}^{-1}$ corresponds to the symmetric and asymmetric $\mathrm{C}-\mathrm{H}$ stretching vibration of aliphatic acids ${ }^{27}$. The peak at $1646.99 \mathrm{~cm}^{-1}$ is due to the characteristic of stretch vibration of $\mathrm{C}=\mathrm{O}$ from carboxylic acid with intermolecular hydrogen bond. The prominent peak at $1419.10 \mathrm{~cm}^{-1}$ is due to the bending vibration of $-\mathrm{C}-\mathrm{H}$. The adsorption peaks observed around $1029.87 \mathrm{~cm}^{-1}$ could be attributed to the bending vibration of $-\mathrm{OH}$ and stretch vibration of C-O-C in lignin structure of the material. As shown in Fig. 1b, after adsorption, the peaks of the stretch vibration of bonded hydroxyl groups and that of $\mathrm{C}=\mathrm{O}$ stretch vibration of carboxylic acid with intermolecular hydrogen bond were shifted from $3403.96 \mathrm{~cm}^{-1}$ and 1646.99 $\mathrm{cm}^{-1}$ to $3411.89 \mathrm{~cm}^{-1}$ and $1654.82 \mathrm{~cm}^{-1}$, respectively.

It was well indicated from FTIR spectrum of sesame leaf that carboxyl and hydroxyl groups were present in abundant supply. These groups may be the potential active sites for interaction with the cationic dye.

Scanning electron micrograph of sesame leaf is shown in Fig. 1. The morphology of sesame leaf exhibits porous structures in a honeycomb shape and the irregular surface. They can facilitate the adsorption of dyes, thus make possible the adsorption of adsorbate in different parts of this material. SEM images clearly showed that the pores were completely filled after the adsorption of Auramine O. From the characterization of sesame leaf powder, the rough surface and functional groups made it's beneficial to adsorb dye cation ion from solution.
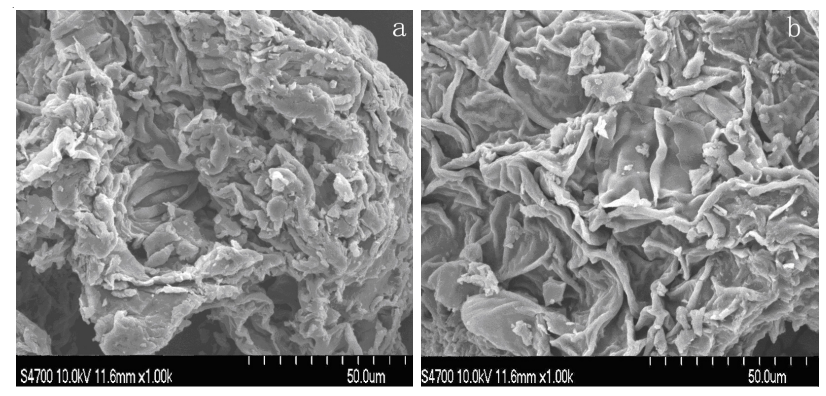

Fig. 1. SEM image of: (a) raw sesame leaf and (b) sesame leaf after adsorption of Auramine $\mathrm{O}$ 
Effect of contact time and initial dye concentration: The plot of adsorption capacity against the contact time at various initial Auramine $\mathrm{O}$ concentrations was revealed in Fig. 2. It was evident from Fig. 2 that the adsorption kinetic behaviour can be divided into three stages: an initial rapid stage where adsorption was fast in the about $0.5 \mathrm{~h}$, then continued with a slower second stage whose contribution to the total Auramine $\mathrm{O}$ adsorption was relatively small during the $0.5-1.5 \mathrm{~h}$ and finally reached a plateau after approximately $1.5 \mathrm{~h}$ of the experiment.

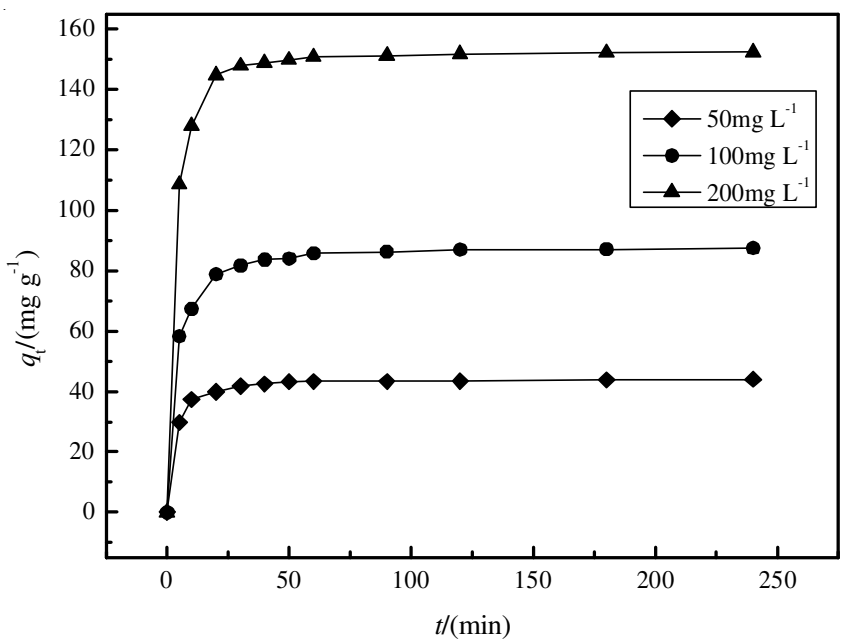

Fig. 2. Effect of contact time on the adsorption of Auramine $\mathrm{O}\left(\mathrm{C}_{0}=50\right.$, 100 and $200 \mathrm{mg} \mathrm{L}^{-1}$; adsorbent concentration $=1 \mathrm{~g} \mathrm{~L}^{-1}$; initial $\mathrm{pH} 7$; $\mathrm{T}=303 \mathrm{~K}$ )

Fig. 2 depicts that the adsorbed amount increased as the time was extended and the equilibrium was attained at about $3 \mathrm{~h}$, at which the maximum removal of Auramine $\mathrm{O}$ occured and the rates of adsorption and desorption nearly equaled. According to the above results, the contact time was chosen at $3 \mathrm{~h}$ in the other batch experiments, which was enough to obtain the full equilibrium. Thus it can be seen that this biosorption proceed is a very fast sorption which is precisely what is the needed for the industry.

Effect of adsorbent dose: Sorbent dosage is an important parameter for the removal dyes from the effluent. It is well known that the higher the dosage of sorbent, the more adsorption sites are here to adsorb more molecules of Auramine O in the solution. However, with the increase in the sesame leaf powder concentration, $\mathrm{q}_{\mathrm{e}}$ may be decreased because of the dispersion by a massive dose of sorbent ${ }^{31}$. Therefore, the effect of the sesame leaf dosage on the removal of Auramine $\mathrm{O}$ was determined. The values of $\mathrm{q}_{\mathrm{e}}$ and the removal percentage of dye $(\mathrm{R} \%)$ at different dose of sesame leaf were presented in Fig. 3. As the sesame leaf powder concentration was increased from 0.20 to $4.0 \mathrm{~g} \mathrm{~L}^{-1}$, the percentage of adsorbed Auramine O increased from 44 to $89 \%$. However, the adsorption capacity $\left(\mathrm{q}_{\mathrm{e}}\right)$ presented the opposite trend. The decrease of $\mathrm{q}_{\mathrm{e}}$ from 220.5 to $22.3 \mathrm{mg} \mathrm{g}^{-1}$ with increasing adsorbent concentration from 0.20 to $4.0 \mathrm{~g} \mathrm{~L}^{-1}$ was attributed to the adsorption competition among adsorbent and the split in the concentration gradient ${ }^{32}$. When the concentration of sesame leaf powder was $1 \mathrm{~g} \mathrm{~L}^{-1}$, the $\mathrm{q}_{\mathrm{e}}$ and $\mathrm{R} \%$ were $78 \mathrm{mg} \mathrm{g}^{-1}$ and $78 \%$, respectively. Considering $\mathrm{q}_{\mathrm{e}}$ and $\mathrm{R} \%$, adsorbent dose of $1 \mathrm{~g} \mathrm{~L}^{-1}$ was found to be the optimum concentration for all other batch experiments.

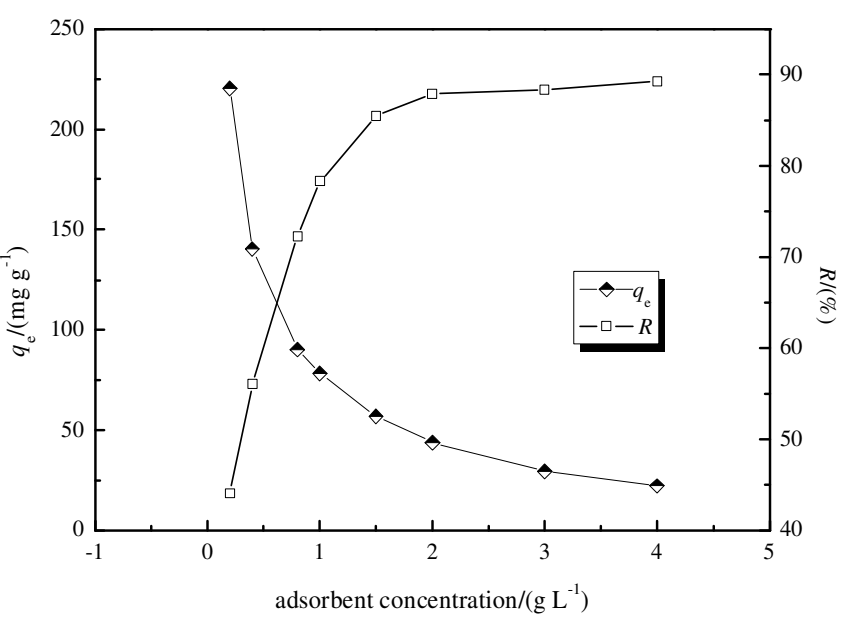

Fig. 3. Effect of adsorbent dose on the adsorption of Auramine $\mathrm{O}\left(\mathrm{C}_{0}=\right.$ $100 \mathrm{mgL} \mathrm{L}^{-1}$; initial $\mathrm{pH} \mathrm{7}$; $=303 \mathrm{~K}$; time $=3 \mathrm{~h}$ )

Effect of initial pH: $\mathrm{pH}$ affects the surface structure of the adsorbent as well as the existence form of Auramine $\mathrm{O}$ in the solution. Hence $\mathrm{pH}$ will affect the adsorption effect of Auramine $\mathrm{O}$ onto sesame leaf powder. The effect of solution $\mathrm{pH}$ on Auramine $\mathrm{O}$ adsorption was investigated according to the following procedure. A series of experiments were conducted between $\mathrm{pH} 1.9$ and 11 , while $\mathrm{C}_{0}$ was fixed at 100 $\mathrm{mg} \mathrm{L}^{-1}$, temperature was maintained at $303 \mathrm{~K}$ and the dose of sesame leaf was $1.0 \mathrm{~g} \mathrm{~L}^{-1}$ (Fig. 4). From Fig. 4 it can be observed that the adsorbed amount of dye was low in low $\mathrm{pH}$ values. The equilibrium adsorption capacity on sesame leaf to Auramine $\mathrm{O}$ increased quickly with the increase of $\mathrm{pH}$ up to 5 and remained nearly constant from $\mathrm{pH} 5$ to 11 . This phenomenon is simply due to the fact that Auramine $\mathrm{O}$ is a cationic dye and Auramine $\mathrm{O}^{+}$is the main form in the solution which can be adsorbed by the sorbent ${ }^{33}$. At lower solution $\mathrm{pH}$, the concentration of $\mathrm{H}^{+}$is higher and $\mathrm{H}^{+}$can create a competitive adsorption with Auramine $\mathrm{O}^{+}$onto sesame leaf. With the increase of $\mathrm{pH}$, the amount of $\mathrm{H}^{+}$decreased in the solution and the surface charges of sesame leaf became negative, which not only removed the interference of $\mathrm{H}^{+}$but also enhanced the attraction forces between Auramine $\mathrm{O}^{+}$and sesame leaf. Therefore, sesame leaf has a significant capacity to adsorb Auramine $\mathrm{O}$ at the higher $\mathrm{pH}(\mathrm{pH}>5)$.

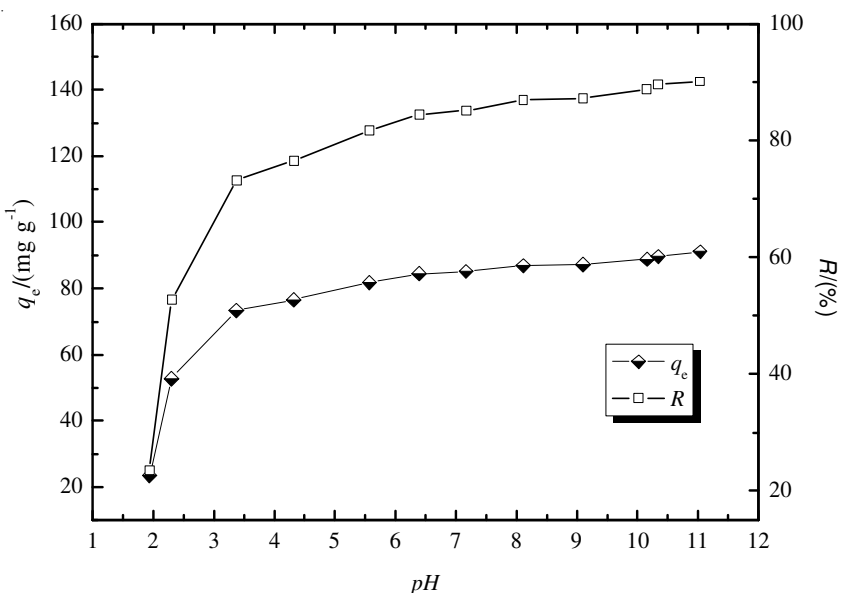

Fig. 4. Effect of $\mathrm{pH}$ on the adsorption of Auramine $\mathrm{O}\left(\mathrm{C}_{0}=100 \mathrm{mg} \mathrm{L}^{-1}\right.$; adsorbent concentration $=1 \mathrm{~g} \mathrm{~L}^{-1} ; \mathrm{T}=303 \mathrm{~K}$; time $=3 \mathrm{~h}$ ) 
Effect of salt ionic strength: There are some salts in the industrial wastewater and natural water. They may interfere with the uptake of dye cation by the adsorbents. To evaluate the effect of ionic strength on the adsorption of Auramine O, adsorption experiments were studied by adding $\mathrm{NaCl}$ and $\mathrm{CaCl}_{2}$ at different concentrations. The results are depicted in Fig. 5, which shows that increasing the concentration of salt in the solution from 0 to $0.30 \mathrm{~mol} \mathrm{~L}^{-1}$ leads to a significant decrease of $\mathrm{q}_{\mathrm{e}}$ and $\mathrm{R} \%$ in Auramine $\mathrm{O}$ adsorption, respectively. The $\mathrm{q}_{\mathrm{e}}$ decreased from $87.1 \mathrm{mg} \mathrm{g}^{-1}$ to $37.1 \mathrm{mg} \mathrm{g}^{-1}$ and $12.3 \mathrm{mg}$ $\mathrm{g}^{-1}$ for $\mathrm{NaCl}$ and $\mathrm{CaCl}_{2}$, respectively. The $\mathrm{R} \%$ decreased from $87.1 \%$ to $37.1 \%$ and $12.3 \%$ for $\mathrm{NaCl}$ and $\mathrm{CaCl}_{2}$, respectively.

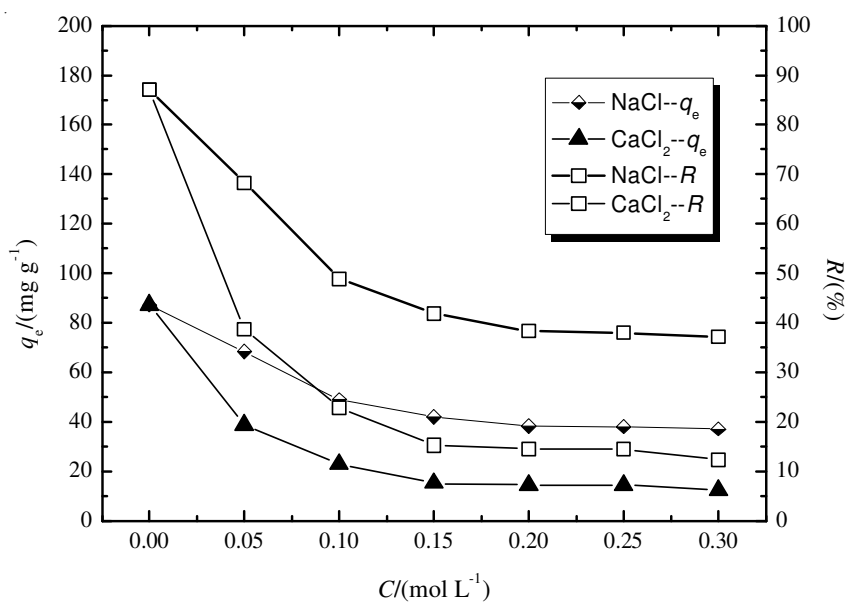

Fig. 5. Effect of salt ionic strength on the adsorption of Auramine $\mathrm{O}\left(\mathrm{C}_{0}=\right.$ $100 \mathrm{mg} \mathrm{L}^{-1}$; adsorbent concentration $=1 \mathrm{~g} \mathrm{~L}^{-1} ; \mathrm{T}=303 \mathrm{~K}$; time $=3 \mathrm{~h}$ )

Because $\mathrm{Na}^{+}$and $\mathrm{Ca}^{2+}$ from $\mathrm{NaCl}$ and $\mathrm{CaCl}_{2}$ may be free in aqueous solution, the salt ions may screen the electrostatic interaction of opposite charges of the adsorbent surface active sites and Auramine $\mathrm{O}$ molecules, so the adsorption capacity should decrease with increasing ionic strength ${ }^{34}$. The effect of $\mathrm{Ca}^{2+}$ is more apparent compared with that of $\mathrm{Na}^{+}$since $\mathrm{Ca}^{2+}$ can screen more negative charges on sesame leaf, thus exhibiting a higher inhibition of Auramine $\mathrm{O}$ adsorption than $\mathrm{Na}^{+}$.

Effect of initial dye concentration on temperaturedependent adsorption: The adsorption experiments were operated at three different temperatures (293, 303 and $313 \mathrm{~K}$ ) with a concentration of $25-250 \mathrm{mg} \mathrm{L}^{-1}$ of Auramine $\mathrm{O}$ to study the effect of temperature on the adsorption rate of Auramine $\mathrm{O}$ onto sesame leaf (Fig. 6). Increasing the temperature can increase the rate of diffusion of the dye molecules and decrease the viscosity of the solution to increase the rates of sorption ${ }^{35}$. On the other hand, it can also increase the rates of desorption. From Fig. 6, it was found that the adsorption capacity decreased as the temperature increased from 293 to $313 \mathrm{~K}$ at every initial concentration. This phenomenon indicated that the adsorption was an exothermic process in nature (Table-1) and the room temperature was the optimum adsorption temperature considering the energy-saving and environmental protection.

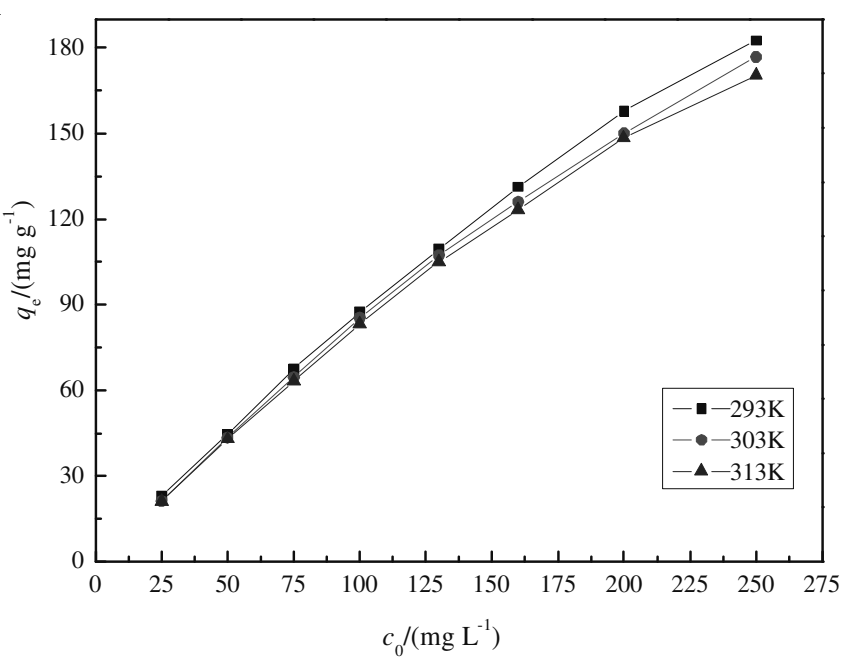

Fig. 6. Effect of initial dye concentration on the adsorption of Auramine $\mathrm{O}\left(\mathrm{T}=293,303\right.$ and $313 \mathrm{~K}$; adsorbent concentration $=1 \mathrm{~g} \mathrm{~L}^{-1}$; time $=3 \mathrm{~h}$ )

Adsorption isotherm: In present study, the experimental data are shown in Table-1. Figs. 7 and 8 were also carried out to analyze the adsorption state of Auramine $\mathrm{O}$ when the adsorption reaction reached equilibrium state. Three common sorption isotherm models were quoted to describe the relationship between the adsorbed amount of dye onto sesame leaf and the dye's equilibrium concentration in the solution. The three isotherm models are Langmuir, Freundlich and Redlich-Peterson.

TABLE-1

ISOTHERM MODEL CONSTANTS OF THREE ISOTHERM MODELS FOR AURAMINE O ADSORPTION ONTO SESAME LEAF $\left(\mathrm{C}_{0}=25-250 \mathrm{mg} \mathrm{L}^{-1} ;\right.$ ADSORBENT CONCENTRATION $=1.0 \mathrm{~g} \mathrm{~L}^{-1}$; TEMPERATURE $=293,303$ and $313 \mathrm{~K}$; TIME $\left.=3 \mathrm{~h}\right)$

\begin{tabular}{|c|c|c|c|c|}
\hline Isotherm model & Constants & $293 \mathrm{~K}$ & $303 \mathrm{~K}$ & $313 \mathrm{~K}$ \\
\hline \multirow[t]{5}{*}{ Langmuir } & $\mathrm{q}_{\mathrm{e}}^{\mathrm{calc}}\left(\mathrm{mg} \mathrm{g}^{-1}\right)$ & $249.2291 \pm 6.3355$ & $244.7104 \pm 10.2378$ & $242.3891 \pm 7.6420$ \\
\hline & $\mathrm{K}_{\mathrm{L}}\left(\mathrm{L} \mathrm{mg}^{-1}\right)$ & $0.0401 \pm 0.0023$ & $0.0335 \pm 0.0031$ & $0.0299 \pm 0.0020$ \\
\hline & $\mathrm{R}_{\mathrm{L}}$ & $0.0907-0.4994$ & $0.1067-0.5442$ & $0.1180-0.5722$ \\
\hline & $\mathrm{R}^{2}$ & 0.9979 & 0.9947 & 0.9972 \\
\hline & $\chi^{2}$ & 2.4063 & 2.4651 & 1.4817 \\
\hline \multirow[t]{3}{*}{ Freundlich } & $\mathrm{K}_{\mathrm{F}}\left[\mathrm{mg} \mathrm{g}^{-1}\left(\mathrm{~L} \mathrm{mg}^{-1}\right)^{1 / \mathrm{n}}\right]$ & $22.2831 \pm 2.8725$ & $18.3020 \pm 2.9631$ & $16.9920 \pm 2.9101$ \\
\hline & $\mathrm{R}^{2}$ & 0.9807 & 0.9735 & 0.9717 \\
\hline & $\chi^{2}$ & 8.3041 & 15.3421 & 18.1998 \\
\hline \multirow[t]{5}{*}{ Redlich-Peterson } & $\mathrm{K}_{\mathrm{RP}}\left(\mathrm{L} \mathrm{mg}^{-1}\right)$ & $11.0988 \pm 1.1198$ & $8.4860 \pm 1.3589$ & $6.9903 \pm 0.6979$ \\
\hline & $\alpha_{\mathrm{RP}}\left(\mathrm{L} \mathrm{mg}^{-1}\right)^{\beta}$ & $0.0664 \pm 0.0277$ & $0.0410 \pm 0.0337$ & $0.0238 \pm 0.0147$ \\
\hline & $\beta_{\mathrm{RP}}$ & $0.9112 \pm 0.0708$ & $0.9631 \pm 0.1464$ & $1.0416 \pm 0.1128$ \\
\hline & $\mathrm{R}^{2}$ & 0.9984 & 0.9948 & 0.9973 \\
\hline & $\chi^{2}$ & 1.9204 & 2.6951 & 1.2891 \\
\hline
\end{tabular}




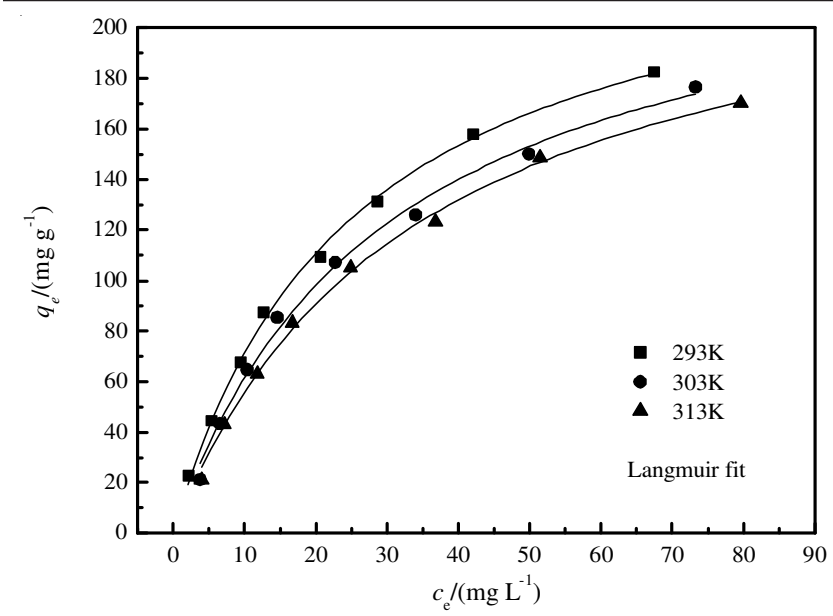

Fig. 7. Langmuir isotherm for adsorption of Auramine $\mathrm{O}$ onto sesame leaf ( $\mathrm{T}=293,303$ and $313 \mathrm{~K} ; \mathrm{C}_{0}=25-250 \mathrm{mg} \mathrm{L}^{-1}$; adsorbent concentration $=1 \mathrm{~g} \mathrm{~L}^{-1}$; time $=3 \mathrm{~h}$ )

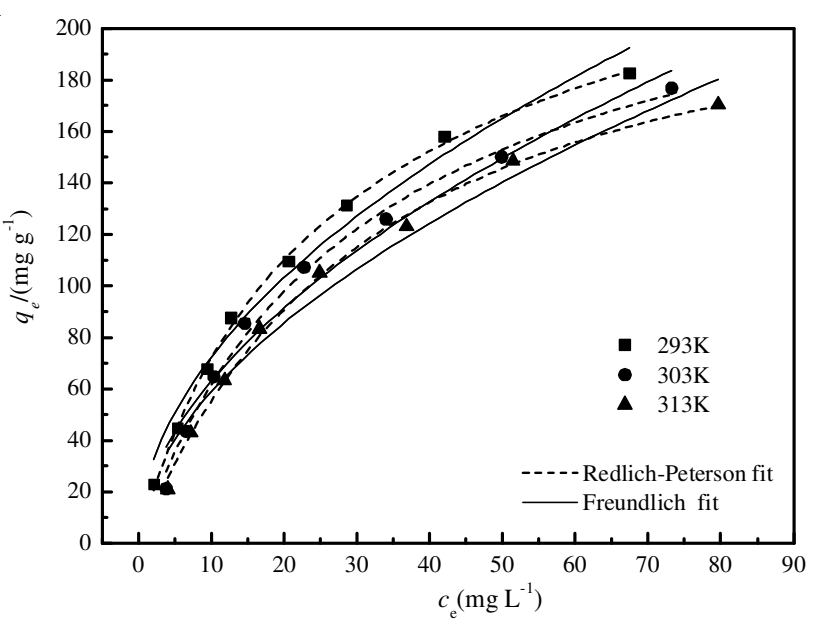

Fig. 8. Freundlich and Redlich-Peterson isotherms for adsorption of Auramine O onto sesame leaf $\left(\mathrm{T}=293,303\right.$ and $313 \mathrm{~K}, \mathrm{C}_{0}=25$ $250 \mathrm{mg} \mathrm{L}^{-1}$; adsorbent concentration $=1 \mathrm{~g} \mathrm{~L}^{-1}$; time $=3 \mathrm{~h}$ )

Langmuir isotherm: Langmuir isotherm ${ }^{36}$ describes a monolayer adsorption state, which supposes that the activity of every site on the surface of sorbent is equal and the sorbate is adsorbed homogeneously without interaction. The Langmuir isotherm model can be depicted in eqn. (4) and it's essential characteristics $\mathrm{R}_{\mathrm{L}}$ (dimensionless separation factor) can be calculated by eqn. (5).

$$
\begin{aligned}
\mathrm{q}_{\mathrm{e}} & =\frac{\mathrm{q}_{\mathrm{m}} \mathrm{K}_{\mathrm{L}} \mathrm{C}_{\mathrm{e}}}{1+\mathrm{K}_{\mathrm{L}} \mathrm{C}_{\mathrm{e}}} \\
\mathrm{R}_{\mathrm{L}} & =\frac{1}{1+\mathrm{K}_{\mathrm{L}} \mathrm{C}_{0}}
\end{aligned}
$$

In eqns. (4) and (5), where $\mathrm{q}_{\mathrm{e}}$ is the equilibrium adsorption capacity per unit weight adsorbent $\left(\mathrm{mg} \mathrm{g}^{-1}\right), \mathrm{q}_{\mathrm{m}}$ is the theoretical maximum adsorption capacity perunit weight adsorbent $\left(\mathrm{mg} \mathrm{g}^{-1}\right), \mathrm{K}_{\mathrm{L}}$ is Langmuir adsorption constant $\left(\mathrm{L} \mathrm{mg}^{-1}\right), \mathrm{C}_{\mathrm{e}}$ is the equilibrium concentration of the solution $\left(\mathrm{mg} \mathrm{L}^{-1}\right), \mathrm{C}_{0}$ is maximum initial Auramine $\mathrm{O}$ concentration $\left(\mathrm{mg} \mathrm{L}^{-1}\right)$ and $\mathrm{R}_{\mathrm{L}}$ is a dimensionless separation factor. The parameter $R_{L}$ indicates the shape of Langmuir isotherm to be either irreversible $\left(\mathrm{R}_{\mathrm{L}}=\right.$ $0)$, favourable $\left(0<R_{L}<1\right)$, linear $\left(R_{L}=1\right)$ or unfavourable $\left(\mathrm{R}_{\mathrm{L}}>1\right)^{37}$.
The plot of $\mathrm{q}_{\mathrm{e}}$ versus $\mathrm{C}_{\mathrm{e}}$ for the adsorption of Auramine $\mathrm{O}$ onto sesame leaf powder at 293, 303 and $313 \mathrm{~K}$ using nonlinear regression of Langmuir isotherm model was shown in Fig. 8. The isotherm data were analyzed and the determined isotherm constants are listed Table-1. The comparison of maximum monolayer adsorption of Auramine $\mathrm{O}$ onto various adsorbents ${ }^{30,38}$ was listed in Table-2, which showed that the sesame leaf powder used in present study had a relatively large adsorption capacity of $249.23 \mathrm{mg} \mathrm{g}^{-1}$ compared to some data obtained from the published literature. The values of $\mathrm{R}_{\mathrm{L}}$ calculated according to eqn. (5) were found to be within the range of $0-1$. The results of analysis indicated that sesame leaf was suitable for removal of Auramine $\mathrm{O}$ from aqueous solution.

\section{TABLE-2}

COMPARISON OF THE MAXIMUM MONOLAYER ADSORPTION OF AURAMINE O ONTO VARIOUS ADSORBENTS

\begin{tabular}{lllll}
\hline $\mathrm{q}_{\mathrm{m}} /\left(\mathrm{mg} \mathrm{g}^{-1}\right)$ & Adsorbent & $\mathrm{T}\left({ }^{\circ} \mathrm{C}\right)$ & $\mathrm{C}_{0}\left(\mathrm{mg} \mathrm{L}^{-1}\right)$ & Ref. \\
\hline 31.177 & Bagasse fly ash & 30 & $5-30$ & 38 \\
1.509 & $\begin{array}{l}\text { Activated carbon- } \\
\text { commercial }\end{array}$ & 30 & $5-30$ & 38 \\
12.552 & $\begin{array}{l}\text { Activated carbon- } \\
\text { laboratory }\end{array}$ & 30 & $5-30$ & 38 \\
249.229 & $\begin{array}{l}\text { Sesame leaf } \\
277.29\end{array}$ & 20 & $25-250$ & $\begin{array}{l}\text { This } \\
\text { study } \\
\text { Poly }(\gamma \text {-glutamic } \\
\text { acid })\end{array}$ \\
\hline
\end{tabular}

Moreover, the $\mathrm{q}_{\mathrm{m}}$ and $\mathrm{K}_{\mathrm{L}}$ decreased with the increasing temperature (Table-1). $\mathrm{K}_{\mathrm{L}}$ represents the equilibrium adsorption constant and relates to the adsorption heat ${ }^{39}$. These figures further verified that the adsorption of Auramine $\mathrm{O}$ onto sesame leaf was exothermic in nature.

Freundlich isotherm: Freundlich isotherm ${ }^{40}$ assumes a multilayer adsorption state, which means that the surface of the sorbent is heterogeneous and the adsorption is a nonuniform distribution of heat. Equation (6) can describe the Freundlich model:

$$
\mathrm{q}_{\mathrm{e}}=\mathrm{K}_{\mathrm{F}} \mathrm{C}_{\mathrm{e}}^{\frac{1}{\mathrm{n}}}
$$

where, $\mathrm{q}_{\mathrm{e}}$ is the equilibrium adsorption capacity per unit weight adsorbent $\left(\mathrm{mg} \mathrm{g}^{-1}\right), \mathrm{K}_{\mathrm{F}}$ is Freundlich adsorption constant (mg $\left.\mathrm{g}^{-1}\left(\mathrm{~L} \mathrm{mg}^{-1}\right)^{1 / \mathrm{n}}\right), \mathrm{C}_{\mathrm{e}}$ is the equilibrium concentration of the solution $\left(\mathrm{mg} \mathrm{L}^{-1}\right), \mathrm{n}$ is the constant depicting the adsorption intensity.

The plot of $\mathrm{q}_{\mathrm{e}}$ versus $\mathrm{C}_{\mathrm{e}}$ for the adsorption of Auramine $\mathrm{O}$ onto sesame leaf powder at 293, 303 and $313 \mathrm{~K}$ using nonlinear regression of Freundlich isotherm model was shown in Fig. 8. The values of $\mathrm{K}_{\mathrm{F}}$ and $1 / \mathrm{n}$ are gained from non-linear regressive analysis of Freundlich isotherm. The results were listed in Table- 1 . The values of $\mathrm{K}_{\mathrm{F}}$ and $1 / \mathrm{n}$ at different temperatures are between $0.10-0.54$ indicating a good adsorption performance for Auramine $\mathrm{O}$ onto sesame leaf powder ${ }^{17}$.

Redlich-Peterson isotherm: Redlich and Peterson ${ }^{41}$ incorporated the features of the Langmuir and Freundlich isotherms into a single equation. The Redlich-Peterson equation is represented as:

$$
\mathrm{q}_{\mathrm{e}}=\frac{\mathrm{K}_{\mathrm{RP}} \mathrm{C}_{\mathrm{e}}}{1+\alpha_{\mathrm{RP}} \mathrm{C}_{\mathrm{e}}^{\beta_{\mathrm{RP}}}}
$$


where $\mathrm{K}_{\mathrm{RP}}$ is the Redlich-Peterson model isotherm constant $\left(\mathrm{L} \mathrm{g}^{-1}\right), \alpha_{\mathrm{RP}}$ the Redlich-Peterson model constant $\left(\mathrm{L} \mathrm{mg}^{-1}\right)^{\beta}$; $\beta_{\mathrm{RP}}$ the Redlich-Peterson model exponent. The exponent, $\beta_{\mathrm{RP}}$, lies between 0 and 1 . There are two limiting behaviours: Langmuir form for $\beta=1$ and Henry's law form for $\beta=0$.

The values of $K_{\mathrm{RP}}, \alpha_{\mathrm{RP}}$ and $\beta_{\mathrm{RP}}$ are obtained from nonlinear regressive analysis of Redlich-Peterson isotherm. The results were listed in Table-1. It can be seen from Table-1, Figs. 7 and 8 that the equilibrium data were excellently fitted by Redlich-Peterson model with correlation coefficients $\mathrm{R}^{2}>$ 0.994 . It was also found that the values of $\beta_{\mathrm{RP}}$ increased while value of $K_{R P}$ and $\alpha_{R P}$ decreased when temperature increased for Auramine $\mathrm{O}$ adsorption. The data can preferably be fitted with Redlich-Peterson model to explain the mechanism of Auramine $\mathrm{O}$ adsorbed onto sesame leaf powder.

Thermodynamic parameters: It has been found that the adsorption capacity decreased with an increase in the temperature, from which the adsorption of Auramine $\mathrm{O}$ onto sesame leaf was preliminarily considered as an exothermic process. Here some critical thermodynamic parameters were determined to confirm the energy change of the adsorption process. Three thermodynamic parameters changes: Gibbs free energy change $\left(\Delta \mathrm{G}^{\mathrm{o}}\right)$, enthalpy change $\left(\Delta \mathrm{H}^{\circ}\right)$ and entropy change $\left(\Delta S^{\circ}\right)$ were calculated by the Van't Hoff equation and Gibbs-Helmholtz equations ${ }^{27}$ :

$$
\begin{gathered}
\Delta \mathrm{G}^{\mathrm{o}}=-\mathrm{RT} \ln \mathrm{K}_{\mathrm{L}} \\
\Delta \mathrm{G}^{\mathrm{o}}=\Delta \mathrm{H}^{\mathrm{o}}-\mathrm{T} \Delta \mathrm{S}^{\mathrm{o}}
\end{gathered}
$$

where, $\Delta \mathrm{G}^{\mathrm{o}}$ is the Gibbs free energy change $\left(\mathrm{kJ} \mathrm{mol}^{-1}\right) ; \Delta \mathrm{H}^{\mathrm{o}}$ is the enthalpy change, $\Delta \mathrm{S}^{\circ}$ is the entropy change, $\mathrm{R}$ is the gas constant $\left(8.314 \mathrm{~J} \mathrm{~K}^{-1} \mathrm{~mol}^{-1}\right)$, $\mathrm{T}$ is the absolute temperature $(\mathrm{K})$ and $\mathrm{K}_{\mathrm{L}}$ is adsorption equilibrium constants from the isotherms models Langmuir.

The $\Delta \mathrm{G}^{\mathrm{o}}$ can be calculated by the Langmuir constant $\left(\mathrm{K}_{\mathrm{L}}\right)$ at different temperature. The value of $\Delta \mathrm{H}^{\circ}$ and $\Delta \mathrm{S}^{\circ}$ were determined from the slope and intercept of a plot of $\Delta \mathrm{G}^{\circ}$ versus $\mathrm{T}$. All the thermodynamic parameters for the biosorption of Auramine $\mathrm{O}$ by sesame leaf are shown in Table-3.

\section{TABLE-3}

THERMODYNAMIC PARAMETERS FOR THE EQUILIBRIUM SORPTION OF AURAMINE O ONTO SESAME LEAF CALCULATED FROM $\mathrm{K}_{\mathrm{L}}\left(\mathrm{t}=3 \mathrm{~h}, \mathrm{C}_{0}=25-250 \mathrm{mg} \mathrm{L}^{-1}\right.$, ADSORBENT CONCENTRATION $=1.0 \mathrm{~g} \mathrm{~L}^{-1}$ )

\begin{tabular}{lccc}
\hline \multirow{2}{*}{ Parameters } & \multicolumn{3}{c}{$\mathrm{T}(\mathrm{K})$} \\
\cline { 2 - 4 } & 293 & 303 & 313 \\
\hline$\Delta \mathrm{G}^{\mathrm{o}}\left(\mathrm{kJ} \mathrm{mol}^{-1}\right)$ & -23.06 & -23.39 & -23.87 \\
$\Delta \mathrm{H}^{\mathrm{o}}\left(\mathrm{kJ} \mathrm{mol}^{-1}\right)$ & & -11.82 & \\
$\Delta \mathrm{S}^{\circ}\left(\mathrm{kJ} \mathrm{mol}^{-1} \mathrm{~K}^{-1}\right)$ & & 40.50 & \\
\hline
\end{tabular}

The negative values of $\Delta \mathrm{G}^{\mathrm{o}}$ indicate the adsorption reaction of Auramine $\mathrm{O}$ onto sesame leaf powder is spontaneous. That $\Delta \mathrm{H}^{\mathrm{o}}$ is negative, the adsorption is a exothermic process and further show the affinity of the sorbent sesame leaf for Auramine O. Additionally, the value of $\Delta \mathrm{S}^{\circ}$ is positive, which shows that the solution system is tending towards stability when the adsorption of Auramine $\mathrm{O}$ onto sesame leaf occurred according to the second law of thermodynamics.
Adsorption kinetics: Fig. 2 illustrated the effect of contact time on adsorption of Auramine $\mathrm{O}$ onto sesame leaf powder at different concentration. A three-stage kinetic behaviour was evident: an initial rapid stage where adsorption was fast in the about $30 \mathrm{~min}$, then continued with a slower second stage whose contribution to the total Auramine $\mathrm{O}$ adsorption was relatively small during the 30-90 min and finally reached a plateau after approximately $90 \mathrm{~min}$ of the experiment.

In study of adsorption, the kinetics of the process is very important to ascertain the steps of rate-controlling and design the appropriate contact time. Some kinetic models are available to describe the mechanism of the adsorption process. The most general models such as pseudo first-order, pseudo secondorder and intra-particle diffusion models have been used to study the adsorption mechanism of Auramine $\mathrm{O}$ onto sesame leaf in this paper.

Pseudo first-order model: The pseudo first-order model of Lagergren describes the relationship of the adsorbed amount and the adsorbed time as $^{42}$ :

$$
\mathrm{q}_{\mathrm{t}}=\mathrm{q}_{\mathrm{e}}\left(1-\mathrm{e}^{-\mathrm{k}_{1} \mathrm{t}}\right)
$$

where, $\mathrm{q}_{\mathrm{e}}$ and $\mathrm{q}_{\mathrm{t}}$ are the adsorption capacity per unit weight of adsorbent $\left(\mathrm{mg} \mathrm{g}^{-1}\right)$ at equilibrium and time $\mathrm{t}(\mathrm{min})$, respectively, and $\mathrm{k}_{1}$ is the rate constant of the pseudo first-order adsorption $\left(\mathrm{min}^{-1}\right)$.

Pseudo second-order model: The pseudo second-order model can be written as ${ }^{43}$ :

$$
\mathrm{q}_{\mathrm{t}}=\frac{\mathrm{k}_{2} \mathrm{q}_{\mathrm{e}}^{2} \mathrm{t}}{1+\mathrm{k}_{2} \mathrm{q}_{\mathrm{e}} \mathrm{t}}
$$

where, $\mathrm{k}_{2}$ is the rate constant of the pseudo second-order adsorption $\left(\mathrm{g} \mathrm{mg}^{-1} \mathrm{~min}^{-1}\right)$.

The initial adsorption rate $\mathrm{h}_{0}\left(\mathrm{mg} \mathrm{g}^{-1} \mathrm{~min}^{-1}\right)$ at $\mathrm{t}=0$ is defined as follows ${ }^{44}$ :

$$
\mathrm{h}_{0}=\mathrm{k}_{2} \mathrm{q}^{2}
$$

The plot of $\mathrm{t} / \mathrm{q}_{\mathrm{t}}$ versus $\mathrm{t}$ (Fig. 10) has been analyzed by linear regression to obtain the parameters of $h_{0}, q_{e}$ and $k_{2}$. The results were listed in Table-4.

From Table-4 and Fig. 9, it can be seen that at each concentration of Auramine $\mathrm{O}$, the pseudo second-order model fits the kinetic data best with the correlation coefficients $\mathrm{R}^{2}>$ 0.98 . Furthermore, the results of error analysis $\chi^{2}$ are relatively small and the values of experimental $\mathrm{q}_{\mathrm{e}, \exp }$ are similar to the calculated $\mathrm{q}_{\mathrm{e}, \text { calc. }}$. All the data imply that the kinetics and mechanism of the adsorption process of Auramine $\mathrm{O}$ onto sesame leaf powder follows the pseudo second-order model.

Table-4 revealed that $\mathrm{h}_{0}$ of the pseudo second-order mode increased from 19.28 to $75.44 \mathrm{mg} \mathrm{g}^{-1} \mathrm{~min}^{-1}$, when the initial concentration increased from 50 to $200 \mathrm{mg} \mathrm{L}^{-1}$. This may be due to the increase of driving force between the liquid and solid phase with the increasing Auramine $\mathrm{O}$ concentration ${ }^{45}$. While the pseudo second-order rate constant $\left(\mathrm{k}_{2}\right)$ showed the opposite trend. The similar result was reported ${ }^{46}$.

Intra-particle diffusion model: The intraparticle diffusion model is used to explain diffusion mechanism of adsorption process. The overall adsorption process may be controlled either by one or more steps, e.g., film diffusion, pore diffusion, surface diffusion and adsorption on the pore surface, or a combination of more than one step. The equation can be described $\mathrm{as}^{47}$ : 


\section{TABLE-4}

KINETIC PARAMETERS OF AURAMINE O ADSORPTION ONTO SESAME LEAF POWDER

$\left(\mathrm{T}=303 \mathrm{~K}, \mathrm{C}_{0}=50,100\right.$ AND $200 \mathrm{mg} \mathrm{L}^{-1}$, ADSORBENT CONCENTRATION $\left.=1.0 \mathrm{~g} \mathrm{~L}^{-1}, \mathrm{n}=11\right)$

\begin{tabular}{|c|c|c|c|}
\hline $\mathrm{C}_{0}\left(\mathrm{mg} \mathrm{L}^{-1}\right)$ & 50 & 100 & 200 \\
\hline \multicolumn{4}{|c|}{ Pseudo first-order model } \\
\hline $\mathrm{q}_{\mathrm{e}}, \exp \left(\mathrm{mg} \mathrm{g}^{-1}\right)$ & 43.9960 & 87.4901 & 152.3581 \\
\hline $\mathrm{q}_{\mathrm{e}}$, calc $\left(\mathrm{mg} \mathrm{g}^{-1}\right)$ & $42.8685 \pm 0.3929$ & $85.7080 \pm 0.9107$ & $149.7219 \pm 1.2195$ \\
\hline $\mathrm{k}_{1}\left(\min ^{-1}\right)$ & $0.2225 \pm 0.0148$ & $0.2285 \pm 0.0179$ & $0.2351 \pm 0.0144$ \\
\hline $\mathrm{R}^{2}$ & 0.9330 & 0.8996 & 0.9365 \\
\hline$\chi^{2}$ & 0.3084 & 0.9050 & 0.9262 \\
\hline \multicolumn{4}{|c|}{ Pseudo second-order model } \\
\hline $\mathrm{q}_{\mathrm{e}, \text { calc }}\left(\mathrm{mg} \mathrm{g}^{-1}\right)$ & $44.7288 \pm 0.2321$ & $89.2203 \pm 0.4085$ & $155.4967 \pm 0.8042$ \\
\hline $\mathrm{h}_{0}\left(\mathrm{mg} \mathrm{g}^{-1} \min ^{-1}\right)$ & 19.2864 & 40.8361 & 75.4392 \\
\hline $\mathrm{k}_{2}\left(\mathrm{~g} \mathrm{mg}^{-1} \mathrm{~min}^{-1}\right)$ & $0.0096 \pm 0.0006$ & $0.0051 \pm 0.0003$ & $0.0031 \pm 0.0002$ \\
\hline $\mathrm{R}^{2}$ & 0.9859 & 0.9877 & 0.9830 \\
\hline$\chi^{2}$ & 3.4774 & 0.0998 & 0.2256 \\
\hline \multicolumn{4}{|c|}{ Intra-particle diffusion model } \\
\hline $\mathrm{k}_{\mathrm{id}, 1}\left(\mathrm{mg} \mathrm{g}^{-1} \min ^{-1 / 2}\right)$ & $4.3639 \pm 1.7352$ & $9.1300 \pm 0.3109$ & $15.9537 \pm 2.2510$ \\
\hline $\mathrm{C}_{1}\left(\mathrm{mg} \mathrm{g}^{-1}\right)$ & $21.2950 \pm 5.9267$ & $38.1029 \pm 1.0619$ & $74.6012 \pm 7.6886$ \\
\hline $\mathrm{R}^{2}$ & 0.8632 & 0.9988 & 0.9805 \\
\hline$\chi^{2}$ & 0.2139 & 0.0037 & 0.1027 \\
\hline $\mathrm{k}_{\mathrm{id}, 2}\left(\mathrm{mg} \mathrm{g}^{-1} \min ^{-1 / 2}\right)$ & $1.2587 \pm 0.1816$ & $2.0927 \pm 0.3785$ & $2.2607 \pm 0.3140$ \\
\hline $\mathrm{C}_{2}\left(\mathrm{mg} \mathrm{g}^{-1}\right)$ & $34.5041 \pm 1.0745$ & $69.8509 \pm 2.2395$ & $135.0130 \pm 1.8577$ \\
\hline $\mathrm{R}^{2}$ & 0.9600 & 0.9386 & 0.9628 \\
\hline$\chi^{2}$ & 0.0060 & 0.0130 & 0.0050 \\
\hline $\mathrm{k}_{\mathrm{id}, 3}\left(\mathrm{mg} \mathrm{g}^{-1} \min ^{-1 / 2}\right)$ & $0.09526 \pm 0.0104$ & $0.4017 \pm 0.0849$ & $0.2189 \pm 0.0214$ \\
\hline $\mathrm{C}_{3}\left(\mathrm{mg} \mathrm{g}^{-1}\right)$ & $42.5147 \pm 0.1159$ & $82.1504 \pm 0.9431$ & $149.1142 \pm 0.2378$ \\
\hline $\mathrm{R}^{2}$ & 0.9542 & 0.8483 & 0.9632 \\
\hline$\chi^{2}$ & 0.1432 & 0.0182 & 0.0006 \\
\hline
\end{tabular}

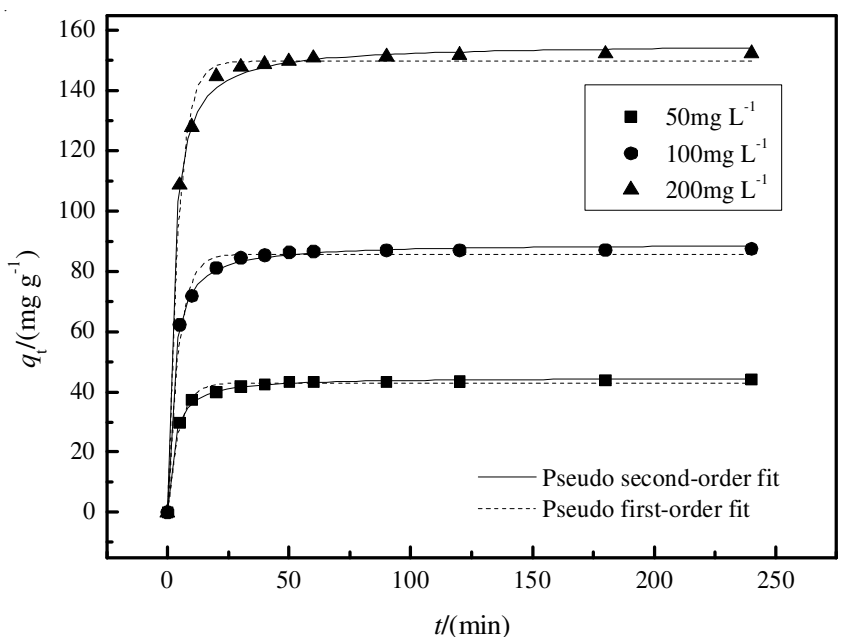

Fig. 9. Pseudo first-order and second-order kinetics for adsorption of Auramine $\mathrm{O}$ onto sesame leaf at different initial dye concentrations $\left(\mathrm{C}_{0}=50,100\right.$ and $200 \mathrm{mg} \mathrm{L}^{-1} ; \mathrm{T}=303 \mathrm{~K}$; adsorbent concentration $=1 \mathrm{~g} \mathrm{~L}^{-1}$; initial $\mathrm{pH}$ 7)

$$
\mathrm{q}_{\mathrm{t}}=\mathrm{k}_{\mathrm{id}} \cdot \mathrm{t}^{1 / 2}+\mathrm{C}_{\mathrm{i}}
$$

where, $\mathrm{k}_{\mathrm{id}}$ is the intra-particle diffusion rate constant $\left(\mathrm{g} \mathrm{mg}^{-1}\right.$ $\left.\mathrm{min}^{-1 / 2}\right), \mathrm{C}$ is the constant $\left(\mathrm{mg} \mathrm{g}^{-1}\right)$ that gives idea about the thickness of the boundary layer, i.e., the larger $\mathrm{C}$ implies the greater effect of the boundary layer.

Fig. 10 presented the plots of $\mathrm{q}_{\mathrm{t}}$ versus $\mathrm{t}^{1 / 2}$ for Auramine $\mathrm{O}$ adsorption. From the linear plot of $\mathrm{q}_{\mathrm{t}}$ against $\mathrm{t}^{1 / 2}$, it is observed that the adsorption process can be divided into three phases. The first phase is the course of surface diffusion correlated to the boundary layer diffusion of adsorbate; the second stage is attributed to the gradual adsorption, where intraparticle diffusion is rate-controlling. The last phase refers to the final equilibrium stage where the intraparticle diffusion starts to slow down because of the extremely low adsorbate concentration in the aqueous solution ${ }^{48}$.

The values of $\mathrm{k}_{\mathrm{id}}$ and $\mathrm{C}_{\mathrm{i}}$ were also listed in Table-4. From Table- 4 the constants of $\mathrm{C}_{\mathrm{i}}$ were not zero, the lines did not pass through the origin. This indicates that the intraparticle diffusion was not the sole rate-controlling step, so the adsorption process may be of a complex nature consisting of both surface adsorption and intra-particle diffusion ${ }^{18}$. Furthermore, all these suggest that the adsorption of Auramine O onto sesame leaf powder may be controlled by external mass transfer followed by intra-particle diffusion mass transfer.

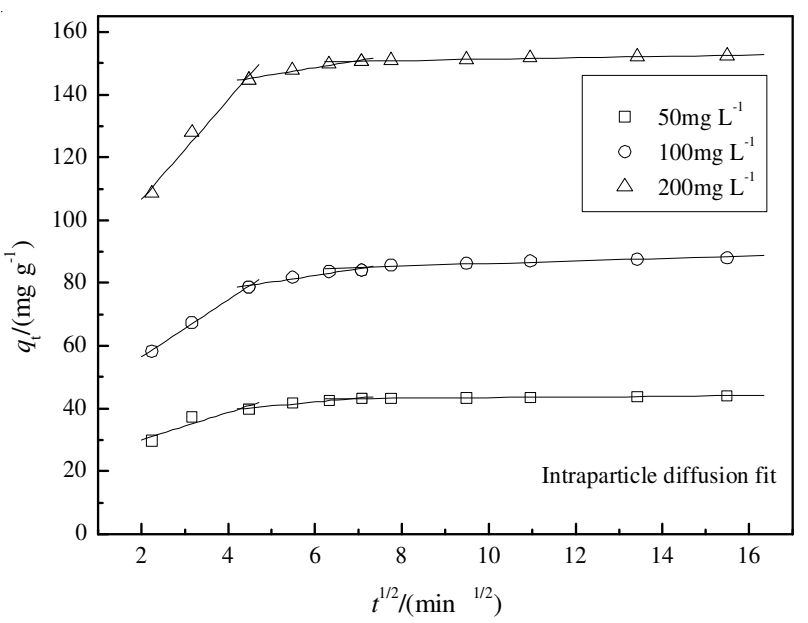

Fig. 10. Intraparticle diffusion model plot for adsorption of $A O$ onto sesame leaf at different initial dye concentrations $\left(C_{0}=50,100\right.$ and 200 $\mathrm{mg} \mathrm{L}^{-1} ; \mathrm{T}=303 \mathrm{~K}$; adsorbent concentration $=1 \mathrm{~g} \mathrm{~L}^{-1}$; initial $\mathrm{pH}$ 7) 


\section{Conclusion}

In this paper, a series of experiments were operated to reveal the adsorption behaviour of sesame leaf removing the cationic dye Auramine $\mathrm{O}$ from aqueous solution. The batch study parameters, $\mathrm{pH}$ of solution, adsorbent concentration, contact time and temperature, were found to be effective on the adsorption efficiency of Auramine O. The experimental data obtained from kinetic and isotherm studies well fitted the pseudo second-order kinetic model and Redlich-Peterson model. The adsorption experiments indicated that the agricultural by-product sesame leaf is a good sorbent for the removal of Auramine $\mathrm{O}$ from aqueous solution.

\section{REFERENCES}

1. R.C. Liu, B. Zhang, D.D. Mei, H.Q. Zhang and J.D. Liu, Desalination, 268, 111 (2011).

2. L.G. Devi, S.G. Kumar, K.M. Reddy and C. Munikrishnappa, J. Hazard. Mater, 164, 459 (2009).

3. L.A. Pérez-Estrada, A. Agüera, M.D. Hernando, S. Malato and A.R. Fernández-Alba, Chemosphere, 70, 2068 (2008).

4. Z.C. Wu, Y. Zhang, T.X. Zhang and H. Fong, Appl. Surf. Sci., 257, 1092 (2010).

5. O.D. Olukanni, A.A. Osuntoki, D.C. Kalyani, G.O. Gbenle and S.P Govindwar, J. Hazard. Mater., 184, 290 (2010).

6. C.H. Niebisch, A.K. Malinowski, R. Schadeck, D.A. Mitchell, V. KavaCordeiro and J. Paba, J. Hazard. Mater, 180, 316 (2010).

7. E. Kusmierek, E. Chrzescijanska, M. Szadkowska-Nicze and J. Kaluzna-Czaplinska, J. Appl. Electrochem., 41, 51 (2011).

8. J.M. Aquino, R.C. Rocha, N. Bocchi and S.R. Biaggio, J. Appl. Electrochem., 40, 1751 (2010).

9. X.S. Zhu, X.S. Jiang, S. Cheng, K. Wang, S.L. Mao and L.J. Fan, J. Polym. Res., 17, 769 (2010).

10. G.M. Nisola, E. Cho, A.B. Beltran, M. Han, Y. Kim and W.J. Chung, Chemosphere, 80, 894 (2010).

11. W.H. Li, Q.Y. Yue, B.Y. Gao, Z.H. Ma, Y.J. Li and H.X. Zhao, Chem. Eng. J., 171, 320 (2011).

12. S. Nethaji, A. Sivasamy, G. Thennarasu and S. Saravanan, J. Hazard. Mater., 181, 271 (2010).

13. S. Mozia, A.W. Morawski, M. Toyoda and T. Tsumura, Desalination, 250, 666 (2010).

14. M.H. Ahmed, T.E. Keyes, J.A. Byrne, C.W. Blackledge and J.W. Hamilton, J. Photochem. Photobiol. A, 222, 123 (2011).

15. P. Bradder, S.K. Ling, S.B. Wang and S.M. Liu, J. Chem. Eng. Data, 56, 138 (2011).

16. B.H. Hameed, I.A.W. Tan and A.L. Ahmad, Chem. Eng. J., 144, 235 (2008).

17. J.Y. Song, W.H. Zou, Y.Y. Bian, F.Y. Su and R.P. Han, Desalination, 265, 119 (2011).
18. V. Vadivelan and K.V. Kumar, J. Colloid Interf. Sci., 286, 90 (2005).

19. V.K. Gupta, R. Jain and S. Varshney, J. Hazard. Mater, 142, 443 (2007).

20. J. Anwar, U. Shafique, Waheed-uz-Zaman, M. Salman, A. Dar and S. Anwar, Bioresour. Technol., 101, 1752 (2010).

21. M.P. Elizalde-González and V. Hernández-Montoya, Bioresour. Technol., 100, 2111 (2009).

22. V.K. Gupta, A. Mittal, A. Malviya and J. Mittal, J. Colloid. Interf. Sci., 355, 24 (2009)

23. V.K. Gupta, A. Mittal, L. Kurup and J. Mittal, J. Hazard. Mater., 151, 834 (2008)

24. R.P. Han, W.H. Zou, W.H. Yu, S.J. Cheng, Y.F. Wang and J. Shi, J. Hazard. Mater, 141, 156 (2007).

25. V. Ponnusami, K.S. Rajan and S.N. Srivastava, Chem. Eng. J., 163, 236 (2010).

26. M. Ertas, B. Acemioglu, M.H. Almaa and M. Ustac, J. Hazard. Mater, 183, 421 (2010).

27. X.L. Han, W. Wang and X.J. Ma, Chem. Eng. J., 171, 1 (2011).

28. E.L.K. Mui, W.H. Cheung, M. Valix and G. McKay, J. Hazard. Mater, 177, 1 (2010)

29. H. Chen, J. Zhao, G.L. Dai, J.Y. Wu and H. Yan, Desalination, 262, 174 (2010).

30. I.D. Mall, V.C. Srivastava and N.K. Agarwal, J. Hazard. Mater, 143, 386 (2007).

31. F. Deniz and S.D. Saygideger, Bioresour. Technol., 101, 5137 (2010).

32. P.S. Kumar, S. Ramalingam, C. Senthamarai, M. Niranjanaa, P. Vijayalakshmi and S. Sivanesan, Desalination, 261, 52 (2010).

33. F.F. Liu, S.X. Teng, R.H. Song and S.G. Wang, Desalination, 263, 11 (2010).

34. L. Wang, J. Zhang, R. Zhao, Y. Li, C. Li and C.L. Zhang, Bioresour. Technol., 101, 5808 (2010).

35. Z. Aksu and G. Karabayur, Bioresour. Technol., 99, 7730 (2008).

36. I. Langmuir, J. Am. Chem. Soc., 38, 2221 (1916).

37. G. Annadurai, L.Y. Ling and J.F. Lee, J. Hazard. Mater, 152, 337 (2008).

38. B.S. Inbaraj, J.T. Chien, G.H. Ho, J. Yang and B.H. Chen, Biochem. Eng. J., 31, 204 (2006).

39. Y.S. Al-Degs, M.I. El-Barghouthi, A.H. El-Sheikh and G.M. Walker, Dyes Pigm., 77, 16 (2008).

40. H.M.F. Freundlich, J. Phys. Chem., 57, 385 (1906).

41. O. Redlich and D.L. Peterson, J. Phys. Chem., 63, 1024 (1959).

42. Y.S. Ho, J.C.Y. Ng and G. McKay, Sep. Purif. Method., 29, 189 (2000).

43. Y.S. Ho and G. McKay, Chem. Eng. J., 70, 115 (1998).

44. A. Khaled, A.E. Nemr, A. El-Sikaily and O. Abdelwahab, J. Hazard. Mater, 165, 100 (2009).

45. B. Noroozi, G.A. Sorial, H. Bahrami and M. Arami, J. Hazard. Mater, 139, 167 (2007).

46. S.J. Allen, Q. Gan, R. Matthews and P.A. Johnson, J. Colloid Interf. Sci., 286, 101 (2005).

47. C.W. Cheung, J.F. Porter and G. Mckay, Sep. Purif. Technol., 19, 55 (2000).

48. L. Abramian and H. El-Rassy, Chem. Eng. J., 150, 403 (2009). 